\title{
TINGKAT PENGETAHUAN DAN SIKAP IBU TERKAIT MAKANAN TAMBAHAN DENGAN STATUS GIZI BALITA DI KECAMATAN WOYLA BARAT
}

\section{(Knowledge and attitudes of mothers related to supplementary food with nutritional status of children in West Woyla District)}

\author{
Maharani $^{1^{*}}$, Sri Wahyuni ${ }^{2}$, DiahFitrianti $^{3}$ \\ ${ }^{1}$ Jurusan Kebidanan Politeknik Kesehatan Kemenkes Aceh, Banda Aceh, Indonesia. \\ E-mail: maharani@poltekkesaceh.ac.id \\ ${ }^{2}$ Program Studi D-III Kebidanan Meulaboh, Jurusan Kebidanan Politeknik Kesehatan Kemenkes Aceh, Indonesia. \\ E-mail: sriwahyuni.arisal@yahoo.com \\ ${ }^{3}$ Program Studi D-III Kebidanan Meulaboh, Jurusan Kebidanan Politeknik Kesehatan Kemenkes Aceh, Indonesia. \\ E-mail: fitriyantidiah@yahoo.com
}

\begin{abstract}
ABSTRAK
Beban ganda masalah gizi sangat mengkhawatirkan anak-anak di Indonesia. Indonesia mempunyai prevalensi kekurangan gizi sebesar 13,8\% dan 3,1\% balita gizi lebih, sedangkan di Aceh yaitu sebesar 16,8\% dan 2,9\% anak gizi lebih. Salah satu faktor penyebab yaitu pengaturan makanan tambahan yang tidak terpola. Tujuan penelitian untuk mengukut hubungan pengetahuan dan sikap ibu tentang makanan tambahan dengan status gizi pada balita di. Penelitian bersifat survey analitik dengan menggunakan pendekatan cross sectional. Sampel diambil sebanyak 86 balita dengan teknik acak sederhana. Pengumpulan data menggunakan kuesioner dan pengukuran antropometri. Data pengetahuan dan sikap diolah menurut nilai persetase, dan data status gizi diolah menurut indeks BB/U. Uji statistik yaitu chi-square pada CI:95\%. Hasil penelitian menunjukan pengetahuan dan sikap ibu tentang makanan tambahan masih kurang baik, serta masih banyak balita yang bestatus gizi kurang. Hasil lainnya menunjukkan hubungan antara pengetahuan ibu $(p=0,000)$ dan sikap ibu $(p=0,019)$ tentang makanan tambahan dengan status gizi pada balita di Kecamatan Woyla Barat Kabupaten. Kesimpulan, pengetahuan dan sikap ibu yang kurang baik tentang pemberian makannan tambahan berhubungan dengan tingginya masalah gizi kurang dan kelebihan gizi. Saran, perlu dilakukan penyuluhan terkait pemberian makanan tambahan yang baik dan bergizi, serta pemantauan status gizi anak secara terus menerus baik pada indeks $B B / U$, $T B / U$ dan $B B / T B$.
\end{abstract}

Kata kunci: Balita, makanan tambahan, pengetahuan dan sikap, status gizi

\begin{abstract}
The double burden of nutrition is very worrying for children in Indonesia. Indonesia has a prevalence of malnutrition of 13,8\% and 3,1\% was overweight of children, while in Aceh that is $16,8 \%$ and 2,9\% of overweight. One of the factors is the arrangement of additional food that is not patterned. The purpose of this study was to examine the relationship between mother's knowledge and attitudes about supplementary food and nutritional status in infants. The study was an analytic survey using a cross sectional approach. Samples were taken as many as 86 toddlers with a simple random technique. Data collection using questionnaires and anthropometric measurements. Knowledge and attitude data are processed according to percentage values, and nutritional status data are processed according index to WFA. The statistical test is chi-square at CI:95\%. The results showed that mothers' knowledge and attitudes about supplementary food were still not good, and there were still many toddlers with the best nutritional status. Other results show the relationship between maternal knowledge $(p=0,000)$ and maternal attitudes $(p=0,019)$ regarding supplementary food with nutritional status in toddlers in Woyla Barat District. Conclusions, poor mother's knowledge and attitude about supplementary feeding is related to the high problem of malnutrition and over nutrition. Suggestions, counseling is needed related to providing good and nutritious supplementary food, as well as monitoring the nutritional status of children continuously both in the WFA, HFA and WFH indexs.
\end{abstract}

Keywords: Toddler, supplement food, knowledge and attitude, nutritional status

${ }^{*}$ Penulis untuk korespondensi: maharani@ poltekkesaceh.ac.id 


\section{PENDAHULUAN}

Terdapat beberapa agenda pembangunan pasca-2015 yang secara spesifik termuat dalam RPJMN 2015-2019, yaitu menurunnya prevalensi underweight menjadi $17,0 \%$ dan prevalensi stunting pada anak di bawah 2 tahun menjadi $28,0 \%$. Selain itu prevalensi wasting menjadi $9,5 \%$ serta prevalensi bayi dengan berat badan lahir rendah (BBLR) menurun dari $10,2 \%$ menjadi $8,0 \% .{ }^{1}$ Gerakan perbaikan gizi dengan fokus terhadap kelompok 1000 hari pertama kehidupan pada tataran global disebut Scaling Up Nutrition (SUN) dan di Indonesia disebut dengan Gerakan Nasional Percepatan Perbaikan Gizi dalam Rangka 1000 Hari Pertama Kehidupan yang disingkat Gerakan $1000 \mathrm{HPK}^{2}$

Negara berpenghasilan rendah dan menengah yang sebelumnya dihadapkan dengan prevalensi kurang gizi yang tinggi sekarang harus menghadapi kelebihan gizi (kelebihan berat badan atau obesitas) sebagai beban tambahan. Kondisi tersebut adalah beban ganda gizi buruk. ${ }^{3}$ Hasil Riset Kesehatan Dasar tahun 2018, ternyata di Indonesia terdapat 3,9\% balita gizi buruk dan $13,8 \%$ balita gizi kurang serta sebesar 3,1\% balita mempunyai kelebihan gizi. Begitu juga dengan Provinsi Aceh, yang berada diatas prevalensi nasional diketahui terdapat balita gizi buruk sebesar 6,7\% dan gizi kurang 16,8\% sedangkan balita dengan kelebihan gizi sebesar $2,9 \%{ }^{4}$

Meningkatnya masalah gizi masih merupakan masalah pokok kesehatan di Negara berkembang adalah masalah gangguan terhadap kesehatan masyarakat yang disebabkan oleh kekurangan gizi. ${ }^{5}$ Masalah gizi di Indonesia masih di dominasi oleh masalah kurang energi protein (KEP), anemia zat besi. Gangguan akibat kekurangan yodium (GAKY) dan kurang vitamin A (KVA). Penyakit gizi kurang banyak ditemui pada masyarakat golongan rentan yaitu golongan yang mudah sekali menderita akibat kurang gizi dan juga kekurangan zat makanan. Status gizi yang kurang baik atau buruk pada anak dapat menimbulkan pengaruh yang tidak baik karena dapat menghambat pertumbuhan dan perkembangannya. ${ }^{6,7}$
Kebutuhan setiap orang akan makanan tidak sama, karena kebutuhan akan berbagai zat gizi juga berbeda. Pengetahuan, sikap, umur, jenis kelamin, macam pekerjaan dan faktor-faktor lain menentukan kebutuhan masing-masing orang akan zat makanan hingga menjadi kurang energi protein (KEP) sehingga sangat mudah terserang penyakit dan dapat berakibat kematian. ${ }^{8}$ Makanan tambahan adalah bahan yang ditambahkan dengan sengaja ke dalam makanan dalam jumlah kecil, dengan tujuan untuk memperbaiki penampakan, cita rasa, tekstur, dan memperpanjang daya simpan. Selain itu dapat meningkatkan nilai gizi seperti protein, mineral dan vitamin Penggunaan aditif makanan telah digunakan sejak zaman dahulu.Bahan aditif makanan ada dua, yaitu bahan aditif makanan alami dan buatan. ${ }^{9,10}$

Berdasarkan Profil Kesehatan Aceh angka kematian bayi di bawah lima tahun (balita) di Provinsi Aceh terus meningkat setiap tahun. Sementara itu, angka gizi buruk menurun. Tahun 2016, tercatat 420 balita menderita gizi buruk dan menurun menjadi 281 kasus pada tahun 2017. Dari 23 Kabupaten yang ada di Aceh, Kabupaten Aceh Barat menduduki peringkat ke 18 untuk masalah gizi pada balita. ${ }^{11}$ Rekapan Dinas Kesehatan Aceh Barat tahun 2017 jumlah seluruh balita dari 13 Wilayah kerja Puskesmas sebanyak 1258 balita dengan klasifikasi laki-laki 7.343 dan perempuan 6.915 balita dari seluruh balita jumlah balita dibawah garis merah sebanyak 173 dengan klasifikasi 96 balita laki-laki dan 77 balita perempuan, kemudian di Puskesmas Pir Batee Puteh jumlah balita sebanyak 639 balita dengan klasifikasi 337 balita laki-laki dan 302 balita perempuan serta balita yang dibawah garis merah sebanyak 18 orang, 9 orang laki-laki dan 9 orang balita perempuan. ${ }^{12}$

Persamalahan gizi sangat identik dengan pengetahuan dan sikap ibu tentang pola asuh. ${ }^{13}$ Beberapa penelitian menemukan bahwa pengetahuan ibu sangat signifikan berdampak terhadap status gizi balita menurut indeks BB/U. Ibu dengan pengetahuan baik cenderung lebih mempunyai anak sehat begitu juga dengan ibu yang bersikap positif. ${ }^{14,15}$ Pengetahuan bertujuan untuk mendapatkan kepastian serta 
menghilangkan prasangka akibat ketidakpastian dan juga untuk mengetahui dan memahami suatu hal lebih dalam. Kurangnya pengetahuan ibu-ibu tentang pentingnya pemantauan pertumbuhan balita berdampak terhadap berat badan anak saat dilakukan pemantauan atau penimbangan di Posyandu. ${ }^{16}$

Menurut Miko \& Dina ${ }^{17}$, terdapat banyak faktor yang mempengaruhi status gizi balita salah satunya adalah asupan nutrisi. Secara langsung asupan nutrisi dapat mempengaruhi status gizi balita, hal ini terjadi apabila asupan makanan atau nutrisi yang diberikan kepada balita tidak sesuai dengan kebutuhan dan tidak seimbang dalam pemberiannya akan mengakibatkan balita mengalami gizi lebih, kurang bahkan gizi buruk. Selain itu, masalah gizi dipengaruhi oleh berbagai faktor pada tingkat individu yaitu asupan gizi dan penyakit infeksi yang saling terkait. Pada tingkat keluarga dan masyarakat yaitu pertama kemampuan keluarga dalam menyediakan pangan bagi anggotanya, Kedua pengetahuan, sikap dan keterampilan keluarga dalam memilih, mengolah dan membagi makanan dan ketiga yaitu kemampuan dan pengetahuan keluarga dalam hal kebersihan pribadi dan lingkungan. ${ }^{18}$

\section{METODE}

Penelitian menggunakan desain potong lintang yang dilakukan secara deskriptif analitik. Lokasi penelitian yaitu dilakukan pada wilayah kerja Puskesmas Pir Batee Puteh Kecamatan Woyla Barat Kabupaten Aceh Barat, karena kurangnya pengetahuan dan sikap ibu terhadap makanan tambahan dengan status gizi pada balita.

Populasi dalam penelitian ini adalah seluruh balita di Wilayah Kerja Puskesmas Pir Batee Puteh Kecamatan Woyla Barat yaitu sebanyak 639. Pengambilan sampel dalam penelitian ini dengan menggunakan rumus sloven dan diperoleh sampel sebanyak 86 balita yang berusia 6 - 59 bulan, yang diambil secara acak.

Data yang dikumpulkan meliputi karakteristik, pengetahuan dan sikap serta status gizi (berat badan, umur, jenis kelamin). Pengumpulan data karakteristik dilakukan secara wawancara menggunakan kuesioner. Sedangkan data berat badan menggunakan timbangan dacin. Pengolahan data dilakukan secara komputerisasi, pengetahuan dan sikap dikelompok menjadi dua kelompok data. Data status gizi menggunakan aplikasi WHO Anthro 2005, status gizi menggunakan indeks $\mathrm{BB} / \mathrm{U}$ dengan katagori mengacu kepada Keputusan Menteri Kesehatan RI Nomor: 1995/Menkes/SK/XII/2010. ${ }^{19}$ Selanjutnya data dilakukan analisis secara univariat dan analisis bivariat menggunakan uji Chi-Square pada CI:95\%.

\section{HASIL DAN PEMBAHASAN}

\section{Karakeristik Responden}

Tabel 1. Distribusi karakteristik responden penelitian

\begin{tabular}{|c|c|c|}
\hline Karakteristik Responden & $\mathrm{n}$ & $\%$ \\
\hline \multicolumn{3}{|l|}{ Umur } \\
\hline Dibawah 20 tahun & 32 & 37,2 \\
\hline $20-35$ tahun & 19 & 22,1 \\
\hline Diatas 35 tahun & 35 & 40,7 \\
\hline \multicolumn{3}{|l|}{ Pendidikan } \\
\hline $\mathrm{SD}$ & 12 & 14,0 \\
\hline SMP & 33 & 38,4 \\
\hline SMA & 31 & 36,0 \\
\hline Sarjana & 10 & 11,6 \\
\hline \multicolumn{3}{|l|}{ Pekerjaan } \\
\hline Tidak bekerja & 51 & 59,3 \\
\hline Bekerja & 35 & 40,7 \\
\hline Jumlah & 86 & 100,0 \\
\hline
\end{tabular}

Responden yaitu ibu-ibu balita yang terpilih dari sampel yaitu sebanyak 86 orang. Berdasarkan hasil penelitian (Tabel 1), diketahui bahwa menurut kelompok usia lebih banyak diatas 35 tahun (40,7\%), sedangkan berdasarkan jenis pendidikan secara umum responden hanya menyelesaikan pendidikan SMP $(38,4 \%)$ dan SMA (36,0\%). Selanjutnya terdapat 59,3\% responden yang tidak bekerja dalam penelitian ini yang dilakukan di Wilayah Kerja Puskesmas Pir Batee Puteh Kecamatan Woyla Barat, Kabupaten Aceh Barat.

\section{Karakeristik Sampel}

Karakteristik sampel yaitu jenis kelamin dan usia. Sampel dalam penelitian ini yaitu balita 
berusia 6 - 59 bulan yang terpilih secara acak di Wilayah Kerja Puskesmas Pir Batee Puteh Kecamatan Woyla Barat.

\section{Tabel 2. Distribusi karakteristik sampel}

\begin{tabular}{|c|c|c|}
\hline $\begin{array}{c}\text { Karakteristik } \\
\text { Sampel }\end{array}$ & $\mathrm{n}$ & $\%$ \\
\hline \multicolumn{3}{|l|}{ Jenis Kelamin } \\
\hline Laki-Laki & 39 & 45,3 \\
\hline Perempuan & 47 & 54,7 \\
\hline \multicolumn{3}{|l|}{ Usia } \\
\hline $6-12$ bulan & 10 & 11,6 \\
\hline $13-24$ bulan & 29 & 33,7 \\
\hline $23-36$ bulan & 35 & 40,7 \\
\hline $37-59$ bulan & 12 & 14,0 \\
\hline Jumlah & 86 & 100,0 \\
\hline
\end{tabular}

Hasil penelitian (Tabel 2) menunjukkan balita yang terpilih sebagai sampel lebih banyak berjenis kelamin perempuan yaitu sebesar 54,7\% dibandingkan dengan laki-laki hanya sebesar $45,3 \%$. Berdasarkan kelompok usia, menunjukan sampel lebih banyak berusia antara 23 - 36 bulan yaitu sebesar $40,7 \%$ dan berusia antara 13 - 24 bulan sebesar $33,7 \%$ di Wilayah Kerja Puskesmas Pir Batee Puteh Kecamatan Woyla Barat.

\section{Pengetahuan dan Sikap Ibu Mengenai Makanan Tambahan}

Tabel 3. Pengetahuan dan sikap ibu tentang makanan tambahan

\begin{tabular}{|c|c|c|}
\hline Makanan Tambahan & $\mathrm{n}$ & $\%$ \\
\hline \multicolumn{3}{|l|}{ Pengetahuan } \\
\hline Baik & 26 & 30,2 \\
\hline Cukup & 17 & 19,8 \\
\hline Kurang & 43 & 52,0 \\
\hline \multicolumn{3}{|l|}{ Sikap } \\
\hline Positif & 34 & 39,5 \\
\hline Negatif & 52 & 60,5 \\
\hline Jumlah & 86 & 100,0 \\
\hline
\end{tabular}

Berdasarkan tabel 3, menggambarkan bahwa ibu-ibu masih mempunyai pengetahuan yang kurang baik tentang pemberian makanan tambahan kepada balita yaitu mencapai 52,0\%, sedangkan ibu dengan pengetahuan baik hanya sebesar 30,2\%. Begitu juga dengan sikap, sebesar 60,5\% ibu-ibu di Wilayah Kerja Puskesmas Pir Batee Puteh Kecamatan Woyla Barat menunjukkan sikap yang masih negatif terkait pemberian makanan tambahan kepada balita mereka. Sikap ibu hampir menunjukkan proporsi yang sama dengan pengetahuannya.

\section{Status Gizi Balita}

Status gizi balita dinilai berdasarkan pengukuran antropometri dan indeks yang digunakan yaitu BB/U. Hasil penelitian sebagaimana telah disajikan pada Tabel 4 menunjukkan bahwa rata-rata umur sampel yaitu 27 bulan dengan berat badan rata-rata adalah 9,7 $\mathrm{kg}$. Z-score indeks BB/U pada sampel mempunyai rata-rata -2,2 dengan deviasi sebesar 1,03.

Tabel 4. Deskripsi antropometri balita

\begin{tabular}{lccc}
\hline \multicolumn{1}{c}{ Antropometri } & Min & Maks & $\begin{array}{c}\text { Rerata } \pm \\
\text { SD }\end{array}$ \\
\hline Umur (bulan) & 9 & 58 & $27,0 \pm 10,23$ \\
Berat Badan $(\mathrm{kg})$ & 6,3 & 28,9 & $9,7 \pm 5,12$ \\
Z-Score (BB/U) & $-2,5$ & 2,9 & $-2,2 \pm 1,03$ \\
\hline
\end{tabular}

Berdasarkan keadaan status gizi balita (Tabel 5), diketahui bahwa balita di Wilayah Kerja Puskesmas Pir Batee Puteh Kecamatan Woyla Barat mempunyai prevalensi gizi kurang sebesar $54,7 \%$.

Tabel 5. Distribusi status gizi balita

\begin{tabular}{lcc}
\hline \multicolumn{1}{c}{$\begin{array}{c}\text { Status Gizi } \\
\text { (indeks BB/U) }\end{array}$} & $\mathrm{n}$ & $\%$ \\
\hline Kurang & 47 & 54,7 \\
Lebih & 10 & 11,6 \\
Baik & 29 & 33,7 \\
\hline \multicolumn{1}{c}{ Jumlah } & 86 & 100,0 \\
\hline
\end{tabular}

\section{Hubungan Tingkat Pengetahuan Ibu dengan Status Gizi Balita}

Hasil penelitian terkait hubungan tingkat pengetahuan ibu dengan status gizi balita di Wilayah Kerja Puskesmas Pir Batee Puteh Kecamatan Woyla Barat disajikan pada Tabel 6 berikut. 
Tabel 6. Hubungan pengetahuan dan sikap tentang makanan tambahan dengan status gizi balita

\begin{tabular}{|c|c|c|c|c|c|c|c|c|c|}
\hline \multirow{3}{*}{ Makanan Tambahan } & \multicolumn{6}{|c|}{ Status Gizi Balita } & \multirow{2}{*}{\multicolumn{2}{|c|}{ Jumlah }} & \multirow{3}{*}{ Nilai $p$} \\
\hline & \multicolumn{2}{|c|}{ Kurang } & \multicolumn{2}{|c|}{ Lebih } & \multicolumn{2}{|c|}{ Baik } & & & \\
\hline & $\mathrm{n}$ & $\%$ & $\mathrm{n}$ & $\%$ & $\mathrm{n}$ & $\%$ & $\mathrm{n}$ & $\%$ & \\
\hline \multicolumn{10}{|l|}{ Pengetahuan } \\
\hline Kurang & 36 & 83,7 & 3 & 7,0 & 4 & 9,3 & 43 & 100,0 & 0,000 \\
\hline Cukup & 6 & 35,3 & 2 & 11,8 & 9 & 52,9 & 17 & 100,0 & \\
\hline Baik & 5 & 19,2 & 5 & 19,2 & 16 & 61,6 & 26 & 100,0 & \\
\hline \multicolumn{10}{|l|}{ Sikap } \\
\hline Negatif & 32 & 61,5 & 8 & 15,4 & 12 & 23,1 & 52 & 100,0 & 0,019 \\
\hline Positif & 15 & 44,1 & 2 & 5,9 & 17 & 50,0 & 34 & 100,0 & \\
\hline Jumlah & 47 & 54,7 & 10 & 11,6 & 29 & 33,7 & 86 & 100,0 & \\
\hline
\end{tabular}

Hasil penelitian (Tabel 6) menunjukkan bahwa sebesar $83,7 \%$ ibu-ibu yang berpengetahuan kurang baik tentang makanan tambahan yaitu mempunyai balita dengan status gizi kurang. Sedangkan ibu dengan pengetahuan baik sebesar $61,6 \%$ balita mereka mempunyai status gizi yang baik. Hasil uji statistik diperoleh nilai $\mathrm{p}=0,000$ pada $\mathrm{CI}: 95 \%$, artinya terdapat hubungan bermakna antara tingkat pengetahuan ibu tentang makanan tambahan dengan status gizi balita di Wilayah Kerja Puskesmas Pir Batee Puteh Kecamatan Woyla Barat, Kabupaten Aceh Barat.

Hasil penelitian tersebut sesuai dengan dengan penelitian yang telah dilakukan sebelumnya oleh Trimanto pada tahun $2008^{20}$, dimana semakin tinggi tingkat pendidikan orang tua maka semakin tinggi kepedulian terhadap kesehatan terutama informasi tentang menjaga status gizi balita. Serta semakin banyak pekerjaan orang tua sebagai ibu rumah tangga, maka orang tua semakin banyak waktu untuk mengasuh dan merawat anaknya sehingga pemenuhan gizi anak terpantau dan tercukupi.

Salah satu faktor yang mempengaruhi status gizi pada balita adalah pengetahuan orang tua dalam memilih dan memberikan makan, karena pengetahuan orang tua mempengaruhi bagaimana orang tua mampu memenuhi persediaan makanan bagi balitanya, mengkonsumsi makanan sesuai gizi yang benar, memilih jenis makanan serta memprioritaskan makanan di tengah keluargannya. ${ }^{21}$ Tingkat pengetahuan orang tua tentang gizi sangat berpengaruh terhadap perilaku dan sikap dalam memilih makanan untuk anaknya. Keadaan gizi yang baik akan menentukan tingginya angka presentase status gizi secara nasional. Ketidaktahuan tentang makanan yang mempunyai gizi baik akan menyebabkan pemilihan makanan yang salah dan rendahnya gizi yang tekandung dalam makanan tersebut dan akan menyebabkan status gizi anak tersebut menjadi buruk dan kurang. ${ }^{22}$

Pengetahuan yaitu pemahaman yang berasal dari pancaindra dan pengalaman yang telah diproses oleh akal budi seseorang dan timbul secara sepontanitas. Sedangkan untuk sifat dari pengetahuan itu sendiri terdiri dari tiga hal, yaitu spontan, intuitif, dan subjektif. Selain itu pengetahuan juga bersifat benar karena sesuai dengan realitas yang ada. ${ }^{16}$ Pengetahuan merupakan suatu landasan berfikir manusia dalam melakukan suatu hal yang berkaitan dengan pencarian jawaban atas pertanyaan yang ada, seperti berkaitan dengan status gizi anak atau balita. ${ }^{23}$

Perhatian dari orang tua terhadap gizi balita akan membuat orang tua lebih mengerti akan pemenuhan gizi yang seimbang untuk balita. Pengetahuan orang tua tentang gizi dan makanan bergizi dapat berubah sewaktu-waktu tergantung dengan apa yang mempengaruhi, seperti pengatahuan yang ddiperoleh tenaga kesehatan seperti bidan desa, kader posyandu, dokter, maupun sumber lain seperti media sosial yang dapat mempengaruhi pengetahuan itu sendiri, khususnya perubahan pengetahuan orang tua balita. 


\section{Hubungan Ibu dengan Status Gizi Balita}

Hubungan sikap ibu tentang makanan tambahan dengan status gizi balita sebagaimana disajikan pad Tabel 6 menunjukkan bahwa, terdapat $61,5 \%$ ibu-ibu yang sikap negatif tentang makanan tambahan mempunyai balita dengan status gizi kurang. Sedangkan ibu-ibu yang bersikap positif mempunyai status gizi yang baik sebesar 50,0\%. Hasil uji statistik diperoleh nilai $\mathrm{p}=0,019$, hal ini menunjukkan bahwa terdapat hubungan bermakna antara sikap ibu tentang makanan tambahan dengan status gizi balita di Wilayah Kerja Puskesmas Pir Batee Puteh Kecamatan Woyla Barat, Kabupaten Aceh Barat.

Berdasarkan hasil temuan dari penelitian menunjukkan bahwa ibu yang memiliki sikap positif juga ada yang memiliki balita gizi kurang, hal ini dikarenakan ada faktor lain yang mempengaruhi status gizi. Pemberian makanan untuk balita banyak mengandung bumbu yang merangsang dan digoreng, selain itu terdapat juga yang memberi makan pada anaknya dengan nasi dan kerupuk tanpa lauk seperti tempe atau telur dan sayuran untuk makanan pokok anak balita, serta terdapat juga yang memberikan jajanan pada anaknya.

Sejalan dengan pendapat yang dikemukan oleh Laraeni et al. ${ }^{24}$, bahwa sikap merupakan faktor yang ada dalam diri manusia yang dapat mendorong atau menimbulkan perilaku tertentu. Jika seorang ibu mempunyai sikap yang baik terhadap gizi akan melahirkan perilaku yang baik pula dalam meningkatkan status gizinya. Hal ini sejalan juga dengan penelitian yang dilakukan oleh Nainggolan ${ }^{14}$, bahwa terdapat hubungan yang signifikan antara sikap gizi ibu dengan status gizi balita. Keadaan ini dapat disebabkan karena sikap ibu merupakan faktor tidak langsung yang mempengaruhi status gizi balita, oleh karena itu meskipun ibu memiliki sikap negatif mengenai gizi balita tetapi jika anak mengkonsumsi makanan yang cukup gizi maka anak tetap akan memiliki status gizi yang baik.

Kekurangan gizi yang terjadi pada balita dapat disebabkan sikap atau perilaku ibu yang menjadi faktor dalam pemilihan bahan makanan yang tidak benar. Pemilihan bahan makanan, tersedianya jumlah makanan yang cukup dan keanekaragaman makanan ini dipengaruhi oleh tingkat makanan yang cukup dan keanekaragaman dipengaruhi oleh tingkat pengetahuan ibu tentang makanan dan gizinya. Keridaktahuan ibu dapat menyebabkan kesalahan pemilihan makanan terutama makanan untuk anak balita. ${ }^{14}$ Ibu yang memiliki sikap positif juga ada yang memiliki balita gizi kurang, hal ini dikarenakan ada faktor lain yang mempengaruhi status gizi. Misalnya, walaupun ibu memiliki sikap positif dalam memberikan makanan tetapi kalau kondisi social ekonomi kurang, pemenuhan nutrisi untuk balita juga akan terganggu. ${ }^{25}$

Kondisi gizi anak yang kurang baik juga bisa terjadi dari ibu yang memiliki sikap positif terhadap gizi anak. Faktor penyebab adalah faktor kesehatan dan lingkungan di sekitar anak. Kedua faktor tersebut merupakan faktor langsung yang juga dapat memengaruhi status gizi anak. Faktor lain yang dapat memengaruhi terjadinya gizi buruk pada anak dilihat dari karateristik ibu adalah produktivitas keluarga. Oleh karena itu walaupun ibu memiliki sikap negatif mengenai gizi balita tetapi jika anak tersebut mengkonsumsi makanan yang memiliki kandungan gizi cukup maka anak tersebut akan tetap memiliki gizi baik, begitu pula sebaliknya. ${ }^{5}$

Kurang memahami dan mengerti tentang tindakan nyata terhadap status gizi balita, ibu tidak paham tentang makanan tambahan yang harus diolah untuk menunjang berat badan dan status gizi balita, hal ini disebabkan karena rendahnya sikap ibu yang mau mengganti menu masakan untuk kecukupan status gizi balita, ibu tidak merinisiatif untuk mengganti menu masakan guna tercukupinya status gizi balita.

\section{KESIMPULAN}

Ibu-ibu masih banyak yang berpengetahuan kurang terkait pemberian makanan tambahan bagi balita, begitu juga sikap mereka tentang pemberian makanan tambahan masih bersikap negatif. Selain itu balita di Kecamatan Woyla Barat lebih banyak yang berstatus gizi kurang. Ibu dengan pengetahuan kurang baik cenderung mempunyai balita dengan status gizi kurang, begitu juga dengan sikap ibu yang negatif. Selanjutnya, terdapat 
hubungan bermakna antara pengetahuan dan sikap ibu tentang pemberian makanan tambahan dengan status gizi balita Kecamatan Woyla Barat Kabupaten Aceh Barat.

Saran, bagi petugas kesehatan khususnya ahli gizi diharapkan secara rutin dapat memberikan penyuluhan kepada orang tua khususnya ibu balita tentang pentingnya pengetahuan dan sikap tentang gizi dan pemberian makanan tambahan pada balita. Selain itu, diharapkan bisa dijadikan masukan bagi masyarakat khususnya ibu-ibu balita yang bersikap negatif tentang gizi kurang pada balita untuk lebih berinisiatif mencari informasi baik dari majalah, koran, TV, atau tenaga kesehatan sehingga masyarakat sadar dan bersikap positif untuk menentukan pola makan pada balita.

\section{DAFTAR PUSTAKA}

1. Miko A, Al-Rahmad AH. Hubungan Berat dan Tinggi Badan Orang Tua dengan Status Gizi Balita di Kabupaten Aceh Besar. Gizi Indonesia. 2017;40(1):21-34.

2. Al Rahmad A, Miko A. Peningkatan Pengetahuan Calon Pengantin melalui Konseling ASI Eksklusif di Aceh Besar. Indonesian Bulletin of Health Research. 2017;45(4):249-256. doi:http://dx.doi.org/10.22435/bpk.v45i4.6 802.249-256.

3. Caleyachetty R, Thomas GN, Kengne AP, Echouffo-Tcheugui JB, Schilsky S, Khodabocus J, Uauy R. The double burden of malnutrition among adolescents: analysis of data from the Global School-Based Student Health and Health Behavior in School-Aged Children surveys in 57 lowand middle-income countries. The American journal of clinical nutrition. 2018;108(2):414-424. doi:https://doi.org/10.1093/ajen/nqy105.

4. Balitbangkes. Riset Kesehatan Dasar 2018. Pertama. Jakarta: Badan Penelitian dan Pengembangan Kesehatan.; 2019.

5. AL-Rahmad AH, Miko A, Hadi A. Kajian stunting pada anak balita ditinjau dari pemberian ASI eksklusif, MP-ASI, status imunisasi dan karakteristik keluarga di Kota Banda Aceh. J Kesehatan Ilmiah
Nasuwakes. 2013;6(2):169-184.

6. Almatsier S. Prinsip Dasar Ilmu Gizi. Edisi ke 9. Jakarta: Gramedia Pustaka Utama; 2013.

7. Sartika RAD. Analisis pemanfaatan program pelayanan kesehatan status gizi balita. Kesmas: National Public Health Journal. 2010;5(2):90-96.

8. Arifin Z. Gambaran Pola Makan Anak Usia 3-5 Tahun Dengan Gizi Kurang Di Pondok Bersalin Tri Sakti Balong Tani Kecamatan Jabon-Sidoarjo. Jurnal Kebidanan Midwiferia. 2016;1(1):16-29.

9. Supariasa I, Bakri B, Fajar I. Penilaian Status Gizi. Jakarta: Buku Kedokteran EGC; 2012.

10. Iskandar I. Pengaruh Pemberian Makanan Tambahan Modifikasi Terhadap Status Gizi Balita. AcTion: Aceh Nutrition Journal. 2017;2(2):120-125.

doi:http://dx.doi.org/10.30867/action.v2i2.6 5.

11. Dinkes Aceh. Profil Kesehatan Aceh Tahun 2017. Banda Aceh; 2018.

12. Dinkes Aceh Barat. Profil Kesehatan Kabupaten Aceh Barat Tahun 2017. Meulaboh, Kabupaten Aceh Barat; 2018.

13. Sarlis N, Ivanna CN. Faktor-faktor yang berhubungan dengan status gizi balita di Puskesmas Sidomulyo Pekanbaru tahun 2016. Jurnal Endurance: Kajian Ilmiah Problema Kesehatan. 2018;3(1):146-152.

14. Nainggolan J, Zuraida R. Hubungan Antara Pengetahuan Dan Sikap Gizi Ibu Dengan Status Gizi Balita Di Wilayah Kerja Puskesmas Rajabasa Indah Kelurahan Rajabasa Raya Bandar Lampung. Jurnal Majority. 2012;1(1):62-73.

15. Jago F, Marni M, Limbu R. Pengetahuan Ibu, Pola Makan Balita, dan Pendapatan Keluarga dengan Status Gizi pada Balita Di Wilayah Kerja Puskesmas Danga Kecamatan Aesesa Kabupaten Nagekeo. Lontar: Journal of Community Health. 2019;1(1):16-22.

16. Al Rahmad AH. Modul pendamping KMS sebagai sarana ibu untuk memantau pertumbuhan balita. AcTion: Aceh Nutrition Journal. 2018;3(1):42-47. doi:http://dx.doi.org/10.30867/action.v3i1.9 
8.

17. Miko A, Dina PB. Hubungan Pola Makan Pagi dengan Status Gizi pada Mahasiswi Poltekkes Kemenkes Aceh. Aceh Nutrition Journal. 2016;1(2):83-87. doi:http://dx.doi.org/10.30867/action.v1i2.1 5.18. Oktarina M. Hubungan sikap ibu dengan status gizi balita di wilayah kerja Puskesmas Sawah Lebar Kota Bengkulu. Medika Respati. 2017;12(4):63-68.

19. Kemenkes. Standar Antropometri Penilaian Status Gizi Anak, Keputusan Menteri Kesehatan RI Nomor: 1995/Menkes/SK/XII/2010. Jakarta:

Direktorat Jenderal Bina Gizi dan Kesehatan Ibu dan Anak. Kementerian Kesehatan Republik Indonesia; 2011.

20. Trimanto A. Hubungan antara tingkat pendidikan ibu, pendapatan keluarga, dan modal sosial dengan status gizi anak balita di Kabupaten Sragen. 2008. https://eprints.uns.ac.id/9594/1/721907072 00903121.pdf.

21. Agus R. Hubungan pengetahuan, sikap, dan tindakan ibu tentang gizi dengan status gizi anak balita (1-5 tahun) di Jorong Surau Laut Wilayah Kerja Puskesmas Biaro Kecamatan IV Angkek Kabupaten Agam tahun 2008.
Jurnal Gizi dan Pangan Vol. 2008;1(2):2328.

22. Maulana LAM. Gambaran Pengetahuan, Sikap dan Tindakan Terhadap Status Gizi Siswa SD Inpres 2 Pannamu. Makasar: Program Studi Ilmu Gizi Fakultas Keseahtan Masyarakat Universitas Hasanudin Makassar. Jurnal Kesmas. 2012;2(3):21-24.

23. Hardiyanti R, Jus'at I, Angkasa D. Hubungan lama kerja menjadi kader, pengetahuan, pendidikan, pelatihan dengan presisi dan akurasi hasil penimbangan berat badan balita oleh kader Posyandu. AcTion: Aceh Nutrition Journal. 2018;3(1):74-81. doi:http://dx.doi.org/10.30867/action.v3i1.1 02.

24. Laraeni $Y$, Sofiyatin $R$, Rahayu $Y$. Hubungan Tingkat Pengetahuan, Sikap, dan Perilaku Ibu Terhadap Konsumsi Zat Gizi (Energi, Protein) pada Balita Gizi Kurang di Desa Labuhan Lombok. Media Bina Ilmih15. 2015;9(1):1-7.

25. Wilujeng R, Supriliyah P. Hubungan sikap ibu dalam memberikan makanan dengan status gizi batita usia 1-3 tahun di desa Puton Kecamatan Diwek Kabupaten Jombang. Jurnal Metabolisme. 2013;2(4):1-5. 